\title{
Analisis Tekno-Ekonomi Hibrid Sistem PLTD PLTS di Pulau Gersik, Belitung Menggunakan Perangkat Lunak HOMER
}

\author{
Julius Christian Hasiholan Simanjuntak ${ }^{1}$; Ginas Alvianingsih² \\ 1,2Institut Teknologi PLN \\ 1 julius1711186@itpln.ac.id
}

\begin{abstract}
Gersik Island is one of the villages in Selat Nasik Subdistrict located in the Belitung Regency. The electrical system in Gersik Island is an isolated system supplied by a diesel power plant. The difficulty of sending diesel fuel to Gersik Island is based on research to combine fossil fuel power plants with solar power plants into a hybrid generating system. Therefore, this study is designed to simulate hybrid generation systems and analyze their feasibility from the technical and economical side using HOMER software. From the simulation results, it is known that the hybrid generating system is feasible to operate from the technical side, with the electricity generated is $268,101 \mathrm{kWh} /$ year. The percentage of loading on this hybrid system is $28.9 \%$ of the solar power plant and $71.1 \%$ of the diesel power plant. From the economic side, the Net Present Cost of a hybrid generation system is lower than the existing diesel power plant, which is Rp17,184,340,000. The Levelized Cost of Energy of the hybrid generating system is also lower than the existing diesel power plant, which is Rp5,144.68/kWh.
\end{abstract}

Keywords: Hybrid Power Plant, HOMER

\begin{abstract}
ABSTRAK
Pulau Gersik adalah salah satu desa di Kecamatan Selat Nasik yang terletak di Kabupaten Belitung. Sistem pembangkit listrik di Pulau Gersik merupakan sistem terisolasi yang disuplai oleh PLTD. Sulitnya pengiriman bahan bakar PLTD ke Pulau Gersik melatarbelakangi penelitian untuk menggabungkan PLTD berbahan bakar fosil dengan PLTS menjadi suatu sistem pembangkit hibrid. Untuk itu penelitian ini bertujun untuk mensimulasikan sistem pembangkit hibrid dan menganalisis kelayakannya dari sisi teknis dan ekonomis menggunakan perangkat lunak HOMER. Dari hasil simulasi diketahui bahwa sistem pembangkit hibrid layak beroperasi dilihat dari sisi teknis, dengan energi listrik yang dihasilkan adalah $268.101 \mathrm{kWh} /$ tahun. Persentase pembebanan pada sistem hibrid ini adalah 28,9\% dari PLTS dan 71,1\% dari PLTD. Dilihat dari sisi ekonomi, Net Present Cost dari sistem pembangkit hibrid lebih rendah daripada PLTD eksisting, yaitu sebesar Rp17.184.340.000. Selain itu Levelized Cost of Energy sistem pembangkit hibrid juga lebih rendah daripada PLTD eksisting, yaitu sebesar Rp5.144,68/kWh.
\end{abstract}

Kata kunci: Pembangkit Listrik Hibrid, HOMER 


\section{PENDAHULUAN}

Listrik sudah menjadi kebutuhan utama untuk menunjang segala kegiatan untuk kehidupan sehari-hari. Indonesia sebagai negara kepulauan memerlukan penyediaan energi listrik dengan cara yang bervariasi. Pulau atau wilayah dengan tingkat kepadatan penduduk yang relatif kecil dipasok oleh sistem terisolasi (isolated system) [1][2] yang umumnya merupakan pembangkit listrik diesel yang yang beroperasi dengan bahan bakar High-Speed Diesel (HSD) atau Marine Fuel Oil (MFO) yang lebih dikenal dengan sebutan minyak solar [3]. Energi fosil yang digunakan sebagai sumber bahan bakar berjumlah sangat terbatas dan akan habis jika digunakan terus-menerus. Selain itu, eksploitasi besar-besaran terhadap energi fosil dapat menyebabkan beberapa masalah lingkungan, antara lain pemanasan global, hujan asam, dan penipisan lapisan ozon [4][5]. PT. PLN (Persero) sebagai perusahaan yang menyediakan energi listrik di Indonesia dituntut agar menemukan sumber energi terbarukan yang bersifat ramah lingkungan seperti Pembangkit Listrik Tenaga Surya[6].

Pulau Gersik adalah salah satu desa di Kecamatan Selat Nasik yang terletak di Kabupaten Belitung, Provinsi Bangka Belitung. Sistem kelistrikan di Pulau Gersik merupakan sistem yang isolated dan tidak dapat terhubung ke jaringan sistem ketenagalistrikan lainnya karena jarak yang jauh antar pulau. Sistem kelistrikan saat ini dipasok dari PLTD Pulau Gersik, dengan kapasitas terpasang 400 kW. Sulitnya mengirimkan BBM menjadi salah satu faktor penting dalam melistriki Pulau Gersik. Mekanisme transportasi BBM ke 53 lokasi yaitu pengiriman BBM dari PLTD Pilang yang berada di kota Tanjung Pandan diangkut dengan truk BBM (trucking) ke Pelabuhan Tanjung Pandan, kemudian BBM dipindahkan ke Tanker Kapal Pengangkut. Setelah tiba di Pulau gersik, BBM dipompa dari posisi jangkar kapal di gersik menuju Tangki BBM PLTD yang berjarak sekitar 20-200 meter tergantung kondisi pasang surut air laut. Hal ini menyebabkan biaya transportasi BBM ke Pulau Gersik sebesar Rp1.144,8/liter.

Sulitnya transportasi penggunaan bahan bakar solar di Pulau Gersik dapat dikurangi dengan menghibrid pembangkit PLTD dengan PLTS yang merupakan pembangkit energi terbarukan. Untuk mengimplementasikan sistem pembangkit hibrid tersebut diperlukan studi kelayakan dari segi teknis dan ekonomis [7][8]. Berdasarkan latar belakang tersebut, penelitian ini bertujuan untuk mensimulasikan sistem pembangkit hibrid di Pulau Gersik, yaitu gabungan antara PLTD eksisting dengan PLTS berkapasitas $40 \mathrm{kWp[9].}$

\section{SISTEM KELISTRIKAN PULAU GERSIK}

Beban listrik di Pulau Gersik terdiri dari 152 pelanggan rumah tangga dengan total energi listrik yang dibangkitkan saat ini rata-rata sebesar 41.742,75 kWh dan beban puncak $42 \mathrm{~kW}$. Beban terdiri dari beban rumah tangga, rumah ibadah (masjid) dan lampu penerangan jalan. Berikut ini adalah grafik dari profil beban listrik Pulau Gersik. 


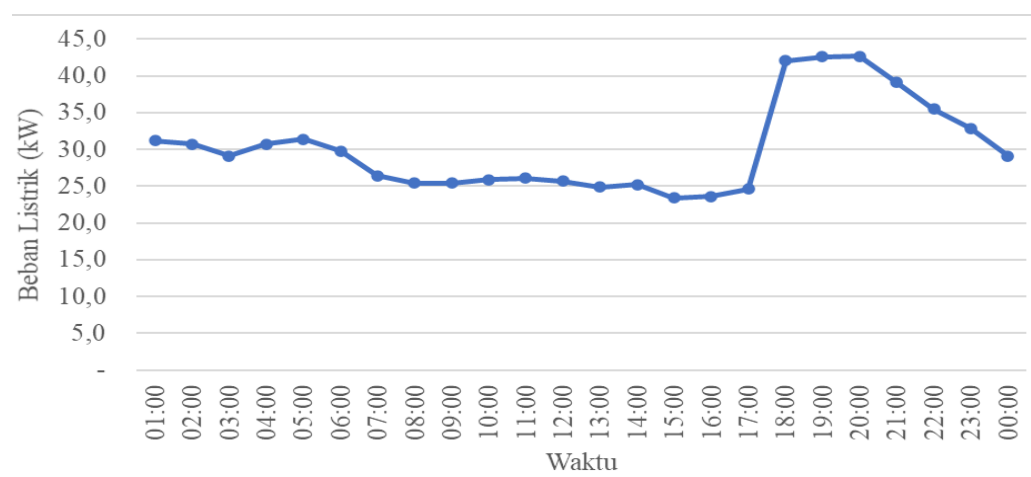

Gambar 1. Profil Beban Listrik Pulau Gersik

\subsection{Pembangkit Listrik Tenaga Diesel (PLTD) Gersik}

Sistem kelistrikan saat ini dipasok dari PLTD Pulau Gersik. Ketersediaan listrik di Pulau Gersik sudah menyala selama 24 jam. PLTD Pulau Gersik yang terdiri dari 4 unit, dengan kapasitas terpasang 400 kW. Specific Fuel Consumption (SFC) dari PLTD Gersik adalah sebesar 0,36 Itr/kWh dengan Biaya Pokok Produksi (BPP) sebesar Rp. 3.204 /kWh. Bahan bakar minyak diesel Rp8.378,52/liter dan biaya pengiriman sampai ke lokasi yaitu sebesar Rp1.449,69/liter, sehingga total biaya bahan bakar menjadi Rp9.828,21/liter. Berikut ini adalah tabel spesifikasi PLTD Gersik.

Tabel 1. Spesifikasi PLTD Gersik

\begin{tabular}{|l|l|l|l|}
\hline Nama & $\begin{array}{l}\text { CAT-500kVA- } \\
50 \mathrm{~Hz}-\mathrm{PP}\end{array}$ & Density $\left(\mathrm{kg} / \mathrm{m}^{3}\right)$ & 820 \\
\hline Manufaktur & Caterpillar Inc. & Carbon Content (\%) & 88 \\
\hline Capacity & $400 \mathrm{~kW}$ & Sulfur Content (\%) & 0,4 \\
\hline Fuel & Diesel & Intial Capital (Rp) & 304.448 .000 \\
\hline Fuel curve intercept & $8,67 \mathrm{~L} / \mathrm{hr}$ & Replacement (Rp) & $202.965 .333,33$ \\
\hline Fuel curve slope & $0,230 \mathrm{~L} / \mathrm{hr} / \mathrm{kw}$ & O\&M (Rp/op. hour) & $3.472,222$ \\
\hline Emission CO (g/L fuel) & 0,97 & Fuel price (Rp/L) & 9828,21 \\
\hline Unburned HC (g/L fuel) & 0,03 & $\begin{array}{l}\text { Minimun Load Ratio } \\
\text { (\%) }\end{array}$ & 1 \\
\hline Particulates (g/L fuel) & 0,06 & $\begin{array}{l}\text { Minimum Runtime } \\
\text { (minutes) }\end{array}$ & 0 \\
\hline Fuel Sulfur to PM (\%) & 0 & Lifetime (hours) & 90.000 \\
\hline NOx (g/L fuel) & 21,12 & Electrical bus & $\mathrm{AC}$ \\
\hline $\begin{array}{l}\text { Lower Heating Value } \\
\text { (MJ/kg) }\end{array}$ & 43,2 & & \\
\hline
\end{tabular}

\subsection{Pembangkit Listrik Tenaga Surya (PLTS) Gersik}

Selain PLTD, Pulau Gersik juga memiliki PLTS Gersik sebesar 40 kWp yang sudah tidak beroperasi. Berikut ini adalah tabel spesifikasi PLTS Gersik. 
Tabel 2. Spesifikasi PLTS Gersik

\begin{tabular}{|c|c|c|c|}
\hline \multicolumn{2}{|c|}{ PV Modul Polycrystalin } & \multicolumn{2}{|l|}{ Baterai } \\
\hline Merk & Solarword & Merk & NS OPZS2 \\
\hline Type & SW 230 & Tegangan Nominal & 2 Volt \\
\hline Rated Max Power & 230 Watt & Kapasitas & $1200 \mathrm{Ah}$ \\
\hline Rated Voltage & 29,8 Volt & Jumlah & 120 baterai \\
\hline Rated Current & 8,25 Ampere & $\begin{array}{l}\text { Nominal } \quad \text { Capacity } \\
(k W h)\end{array}$ & 3,37 \\
\hline Open Current Voltage & 36,9 Volt & Capacity Ratio & 0,201 \\
\hline Short Circuit Current & 6,82 Ampere & Rate Constant (1/hr) & 2,08 \\
\hline Max System Voltage & 1000 Volt & Roundtrip efficiency (\%) & 95 \\
\hline Panel Type & Flat Plate & $\begin{array}{ll}\text { Maximum } & \text { Charge } \\
\text { Current }(A) & \end{array}$ & 557 \\
\hline Temperature Coefficient & $-0,45600$ & $\begin{array}{l}\text { Maximum Discharge } \\
\text { Current }\end{array}$ & 1,09E+03 \\
\hline $\begin{array}{l}\text { Operating temperature } \\
\left({ }^{\circ} \mathrm{C}\right)\end{array}$ & 47,2 & $\begin{array}{l}\text { Maximum Charge Rate } \\
(A / A h)\end{array}$ & 1 \\
\hline Efficiency (\%) & 13 & Capital (Rp) & 840.000 .000 \\
\hline Konfigurasi & 3 String & Replacement (Rp) & 560.000 .000 \\
\hline Jumlah & 175 Modul & O\&M (Rp/year) & $549.176,21$ \\
\hline Capital Cost (Rp) & 700.000 .000 & String size & 1 \\
\hline Replacement (Rp) & $466.666 .666,67$ & Time (years) & 20 \\
\hline O\&M (Rp/year) & 2.100 .000 & Throughput (kWh) & 4.209 \\
\hline Lifetime (years) & 25 & $\begin{array}{l}\text { Initial State of Charge } \\
(\%)\end{array}$ & 100 \\
\hline Derating Factor (\%) & 100 & $\begin{array}{l}\text { Minimum State of } \\
\text { Charge (\%) }\end{array}$ & 20 \\
\hline Sizing & 40,25 & \multicolumn{2}{|c|}{ Bidirectional Inverter } \\
\hline Electrical Bus & $\mathrm{DC}$ & Merk & Leonic \\
\hline \multicolumn{2}{|c|}{ MPPT Charger Controller } & Jumlah & 3 buah \\
\hline Merk & Appolo & & \\
\hline Tipe & MTP-616F & & \\
\hline Daya Keluaran & $45 \mathrm{~kW}$ & & \\
\hline Capital (Rp) & 400.000 .000 & & \\
\hline Replacement (Rp) & 266.666 .667 & & \\
\hline O\&M (Rp/year) & $26.666 .666,67$ & & \\
\hline Lifetime Inverter (years) & 15 & & \\
\hline Efficiency Inverter (\%) & 95 & & \\
\hline $\begin{array}{ll}\text { Relative } & \text { Capacity } \\
\text { Rectifier (\%) } & \end{array}$ & 100 & & \\
\hline Efficiency Rectifier (\%) & 95 & & \\
\hline
\end{tabular}




\section{METODE PENELITIAN}

\subsection{Perangkat Lunak HOMER}

HOMER (Hibrid Optimization Model for Energy Renewable) merupakan perangkat lunak yang dapat mensimulasikan sistem pembangkit skala kecil untuk memudahkan evaluasi desainnya. Adapun sistem pembangkit yang disimulasikan dapat terdiri dari beberapa jenis pembangkit, baik pembangkit energi terbarukan maupun tidak, baik terinterkoneksi ataupun tidak [10][11]. HOMER melakukan penyeimbangan energi pada tiap-tiap konfigurasi sistem yang dimungkinkan, kemudian menentukan kelayakan dari konfigurasi-konfigurasi tersebut berdasarkan kebutuhan beban listrik dan parameterparameter ekonomi.

Secara teknis, dalam simulasi HOMER akan menyeimbangkan kebutuhan listrik pada sistem dengan energi yang dihasilkan dari tiap-tiap pembangkit pada setiap jamnya. Jika sistem terdiri dari baterai dan generator, HOMER dapat menentukan waktu pengoprasian generator. Sedangkan dari sisi ekonomi, kelayakan dinilai dari parameter Net Present Cost (NPC) dan Levelized Cost of Energy (LCOE)[12][13]. NPC adalah jumlah dari biaya modal komponen pembangkit (capital cost), biaya pergantian komponen (replacement cost), biaya operasional dan perawatan (operation and maintenance cost), biaya bahan bakar, dan biaya yang tersisa pada komponen[14]. Sedangkan LCOE adalah parameter yang menggambarkan total biaya tahunan yang digunakan untuk pembangkit (Rp/tahun) dibagi dengan total energi tahunan yang tersedia untuk beban (kWh)[15].

\subsection{Simulasi}

Tujuan dari penelitian ini adalah untuk mensimulasikan PLTD dan PLTS yang telah tidak beroperasi tersebut. Skema aliran daya PLTS Pulau Gersik dapat dilihat pada gambar di bawah ini.

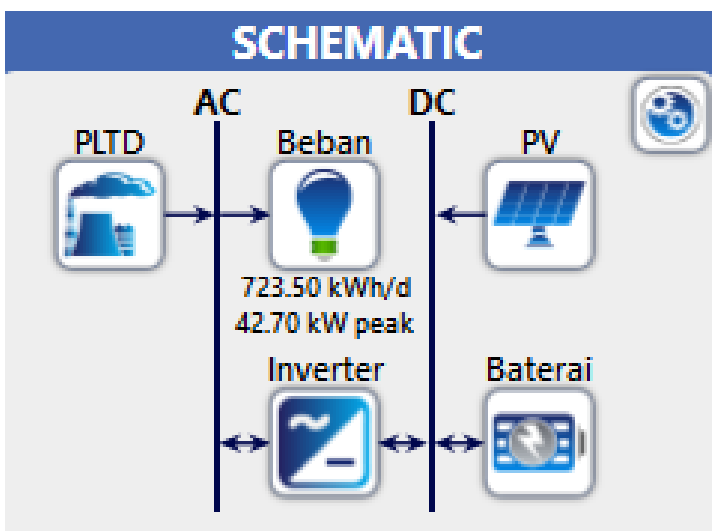

Gambar 2. Skematik Rancangan Sistem Pembangkit Hibrid Pulau Gersik Pada Software HOMER

Berikut ini adalah tampilan hasil input parameter-parameter dari setiap komponen pembangkit. 
Vol. 11, No. 1, Juni 2021, P-ISSN 2356-1505, E-ISSN 2656-9175

https://doi.org/10.33322/sutet.v11i1.1372

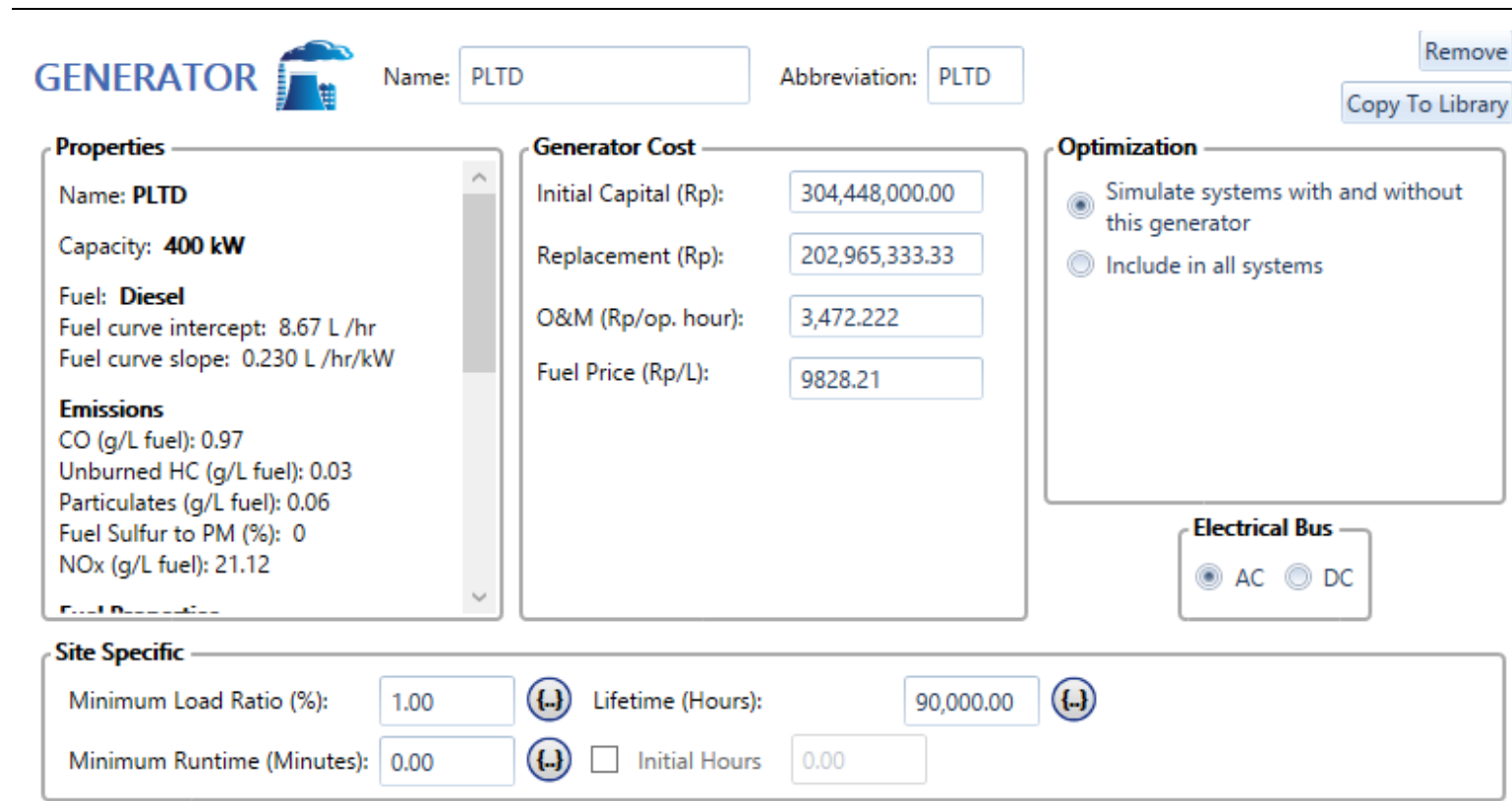

Gambar 3. Hasil Input Data PLTD Pada Software HOMER

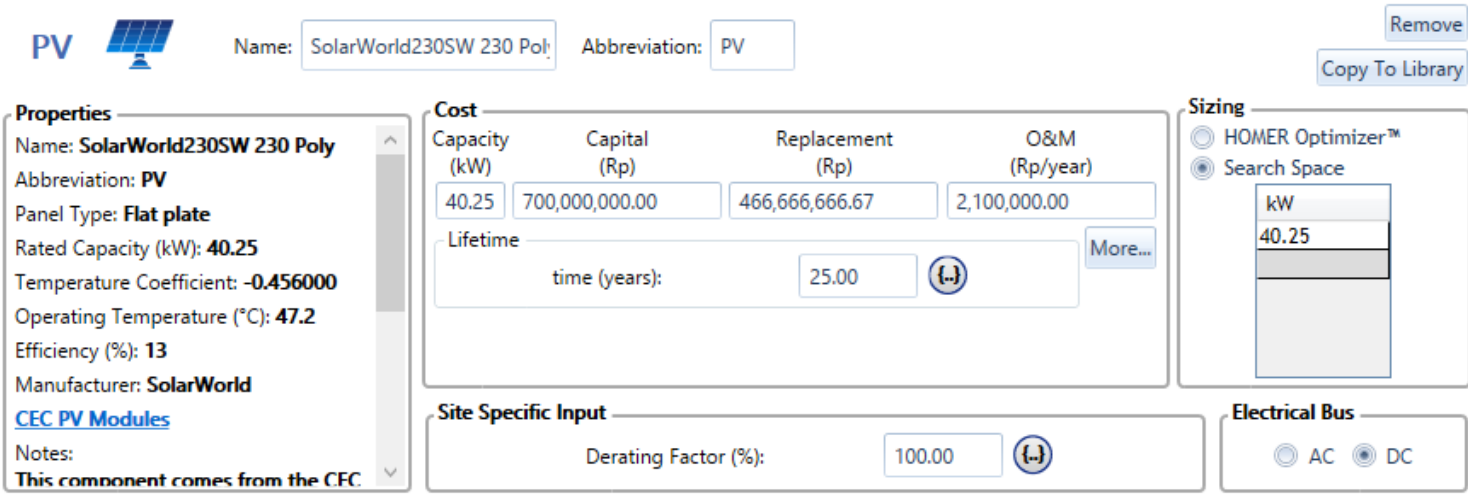

Gambar 4. Hasil Input Data PV Pada Software HOMER

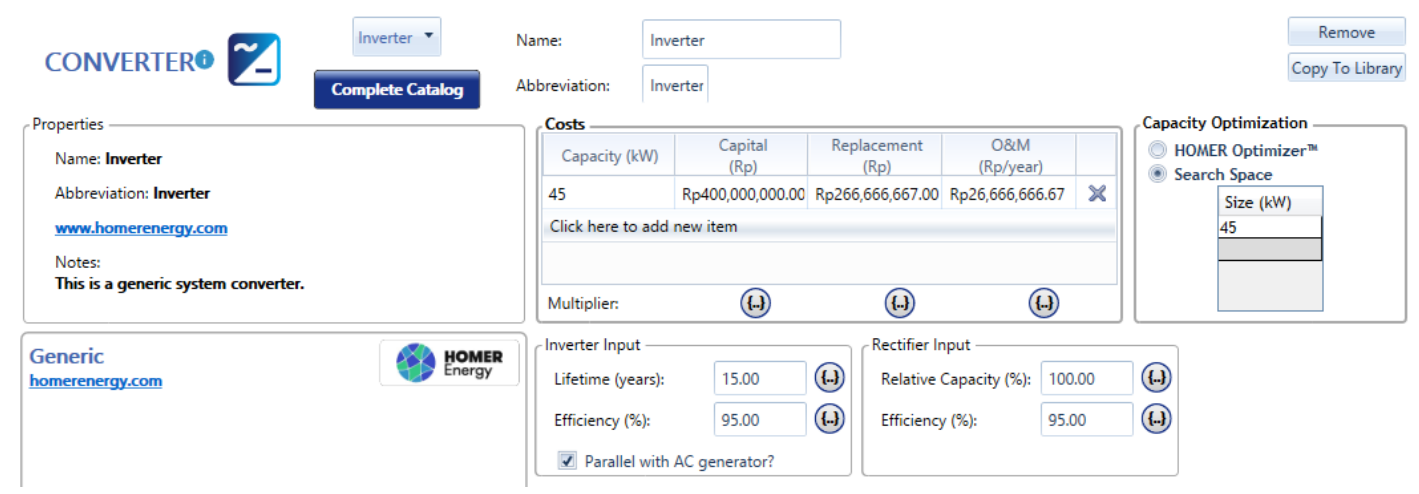

Gambar 5. Hasil Input Data Inverter Pada Software HOMER 


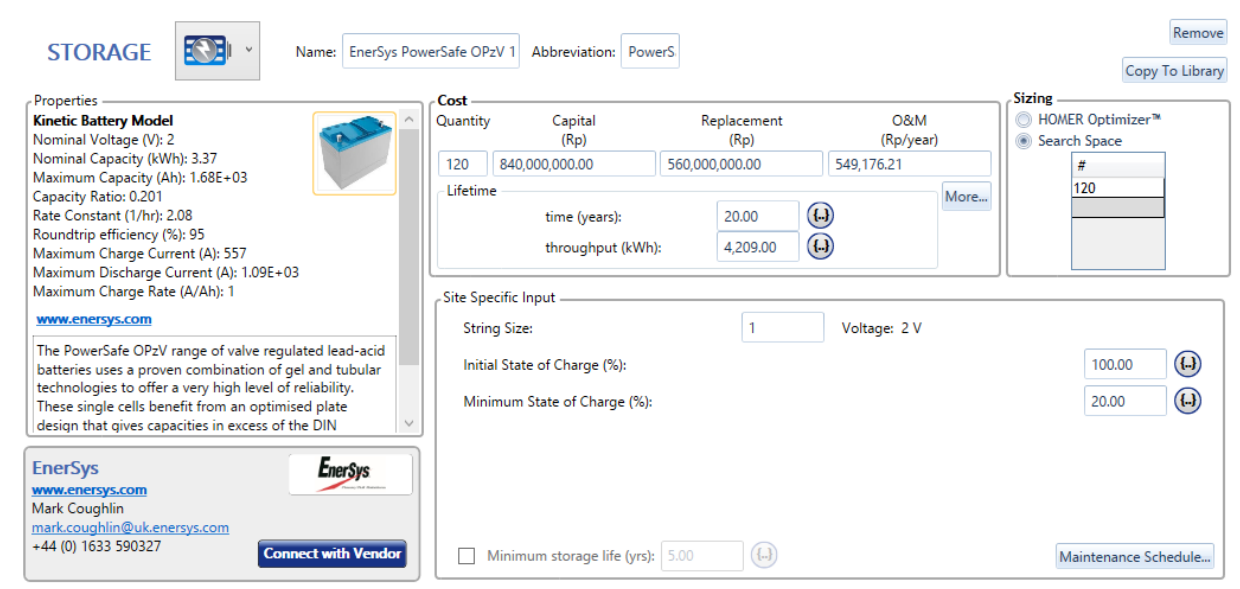

Gambar 6. Hasil Input Data Baterai Pada Software HOMER

\section{HASIL DAN PEMBAHASAN}

\subsection{Kelayakan Pembangkit Hibrid Dari Sisi Teknis}

Aspek teknis bertujuan untuk menghitung dan membandingkan antara pembebanan pada komponen pembangkit sebelum dan sesudah adanya PLTS, sehingga dapat dinilai kelayakan dari sistem hibrid yang diajukan secara teknis. Dari simulasi yang dilakukan, didapati output beban pada PLTD Pulau Gersik sebelum dihibrid sebagai berikut:

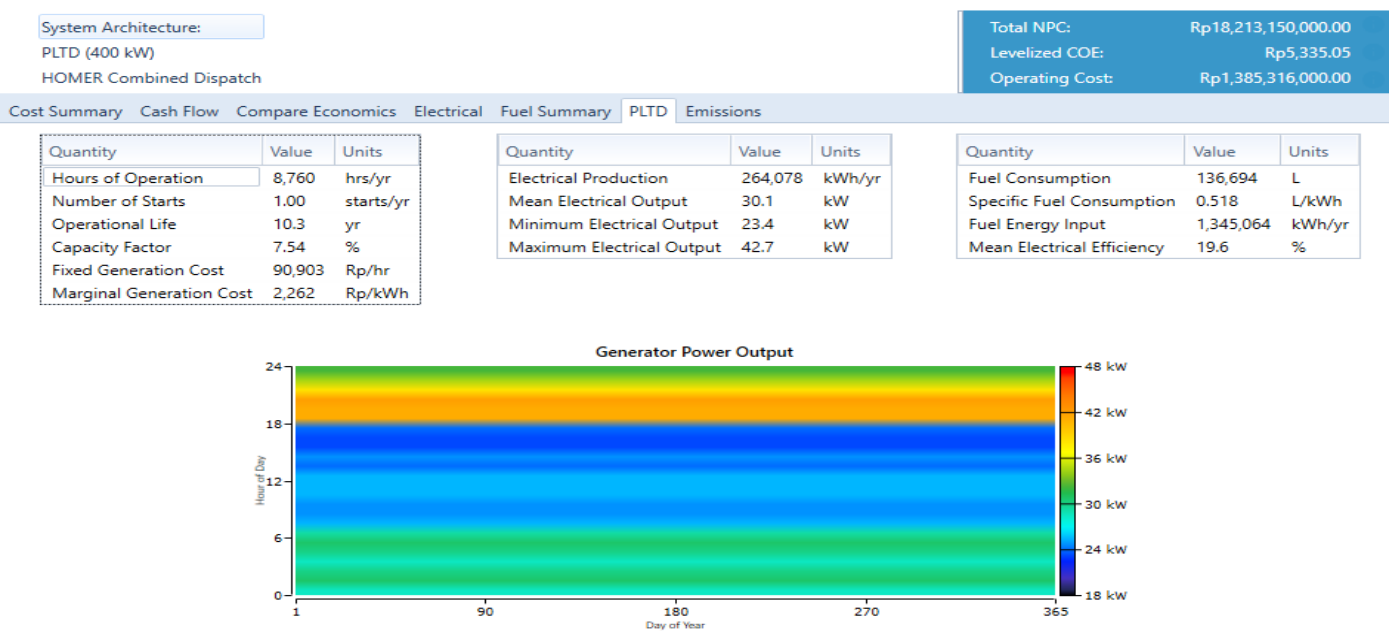

Gambar 7. Hasil Simulasi PLTD Sebelum Dihibrid Dengan PLTS

Dari Gambar 7 dapat dilihat bahwa PLTD beroperasi selama 8.760 jam per tahun dan menghasilkan tenaga listrik sebesar 264.078 per tahun. Berikut ini adalah hasil simulasi setelah PLTD dihibrid dengan PLTS. 


\begin{tabular}{|c|c|c|}
\hline \multicolumn{3}{|l|}{ Simulation Results } \\
\hline \multicolumn{3}{|l|}{ System Architecture: } \\
\hline \multicolumn{3}{|c|}{ SolarWorld230SW 230 Poly $(40.3 \mathrm{~kW})$ Inverter (- } \\
\hline \multicolumn{2}{|l|}{ PLTD $(400 \mathrm{~kW})$} & DMER \\
\hline \multicolumn{3}{|l|}{ Inverter Emissions } \\
\hline \multicolumn{3}{|c|}{ Cost Summary Cash Flow Compare Economics } \\
\hline Production & $\mathrm{kWh} / \mathrm{yr}$ & $\%$ \\
\hline SolarWorld230SW 230 Poly & 77,488 & 28.9 \\
\hline PLTD & 190,614 & 71.1 \\
\hline Total & 268,101 & 100 \\
\hline
\end{tabular}
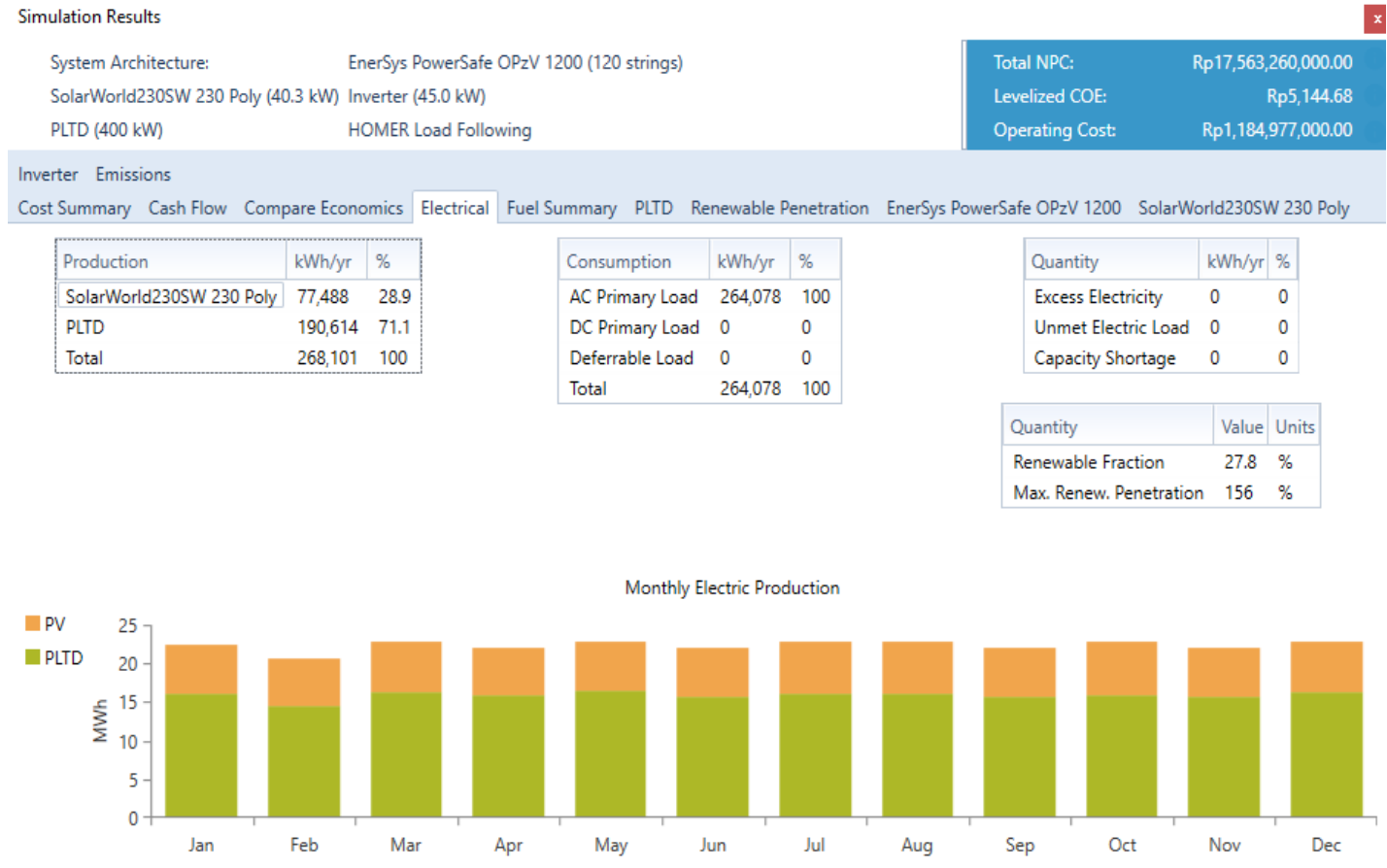

Gambar 8. Hasil Simulasi PLTD Setelah Dihibrid Dengan PLTS

Dari simulasi yang dilakukan, dapat diketahui bahwa pasokan listrik yang dihasilkan oleh PLTD sebesar $190.614 \mathrm{kWh}$ per tahun sedangkan PV sebesar $77.488 \mathrm{kWh}$ per tahun. Total energi listrik yang dihasilkan dari sistem hibrid berjumlah $268.101 \mathrm{kWh}$ per tahun.

\subsection{Kelayakan Pembangkit Hibrid Dari Sisi Ekonomi}

\subsubsection{Parameter Net Present Cost}

Hasil simulasi yang dilakukan untuk mendapatkan NPC pada PLTD eksisting dapat dilihat dari gambar di bawah ini.

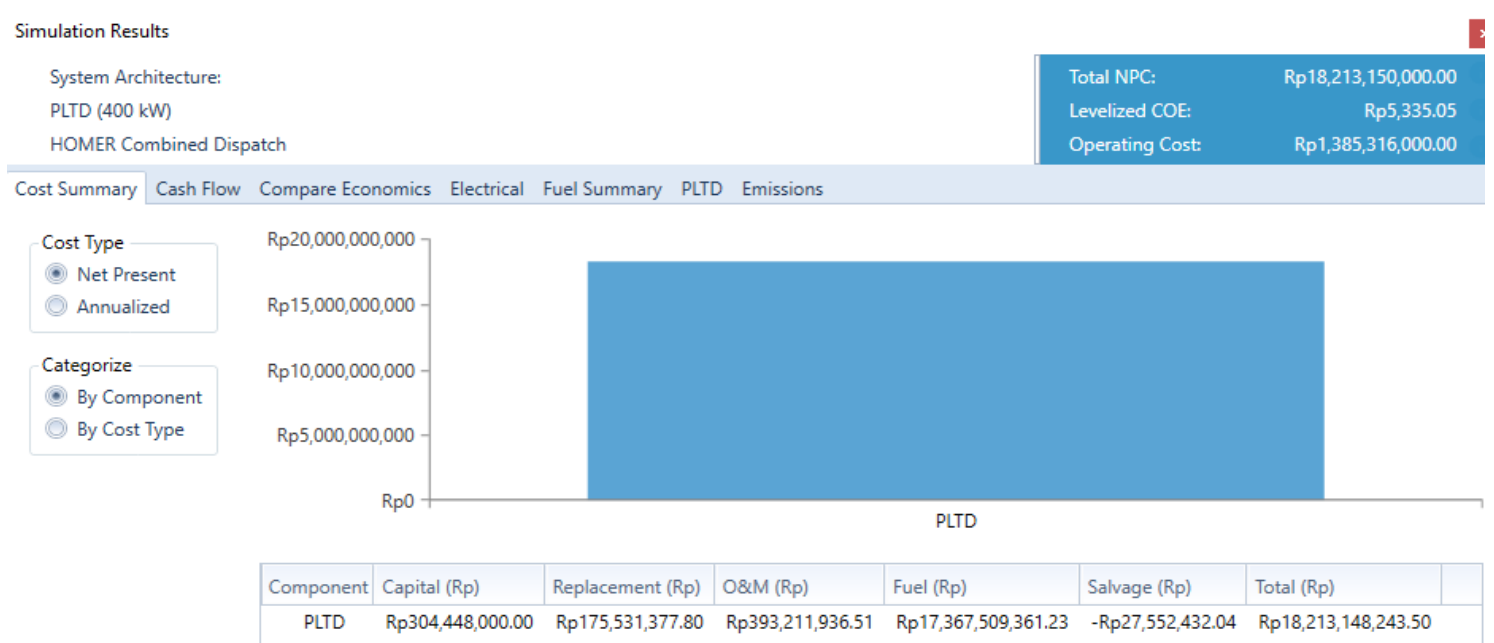

Gambar 9. NPC PLTD Eksisting Sebelum Dihibrid Dengan PLTS

Dari Gambar 9 dapat diketahui bahwa NPC pada PLTD yang saat ini telah ada di Pulau Gersik adalah sebagai berikut: 


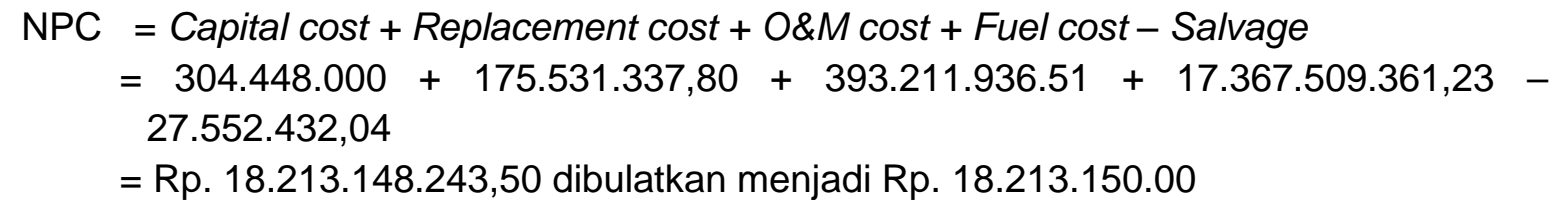

Hasil simulasi yang dilakukan untuk mendapatkan NPC pada sistem hibrid PLTD dan PLTS dapat dilihat dari Gambar 10.

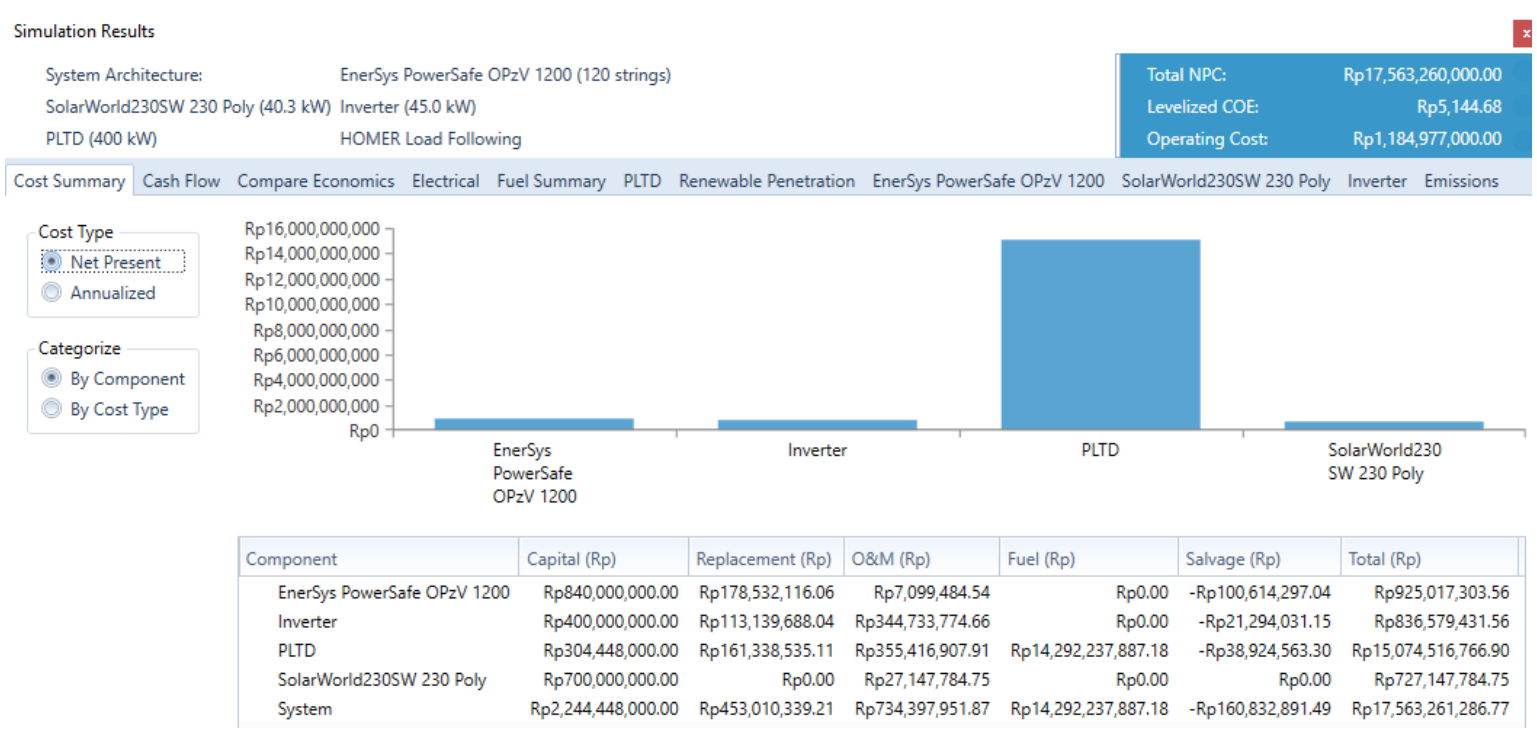

Gambar 10. NPC PLTD Setelah Dihibrid Dengan PLTS

Dari simulasi yang dilakukan dapat diketahui bahwa sistem pembangkit hibrid yang direncanakan memiliki NPC yang lebih rendah daripada PLTD yang saat ini telah beroperasi di Pulau Gersik. Hasil ini mengindikasikan bahwa sistem pembangkit hibrid yang direncanakan layak berdasarkan parameter NPC.

\subsubsection{Parameter Levelized Cost of Energy}

Hasil simulasi yang dilakukan guna mendapatkan LCOE pada PLTD eksisting dapat dilihat dari Gambar 11.

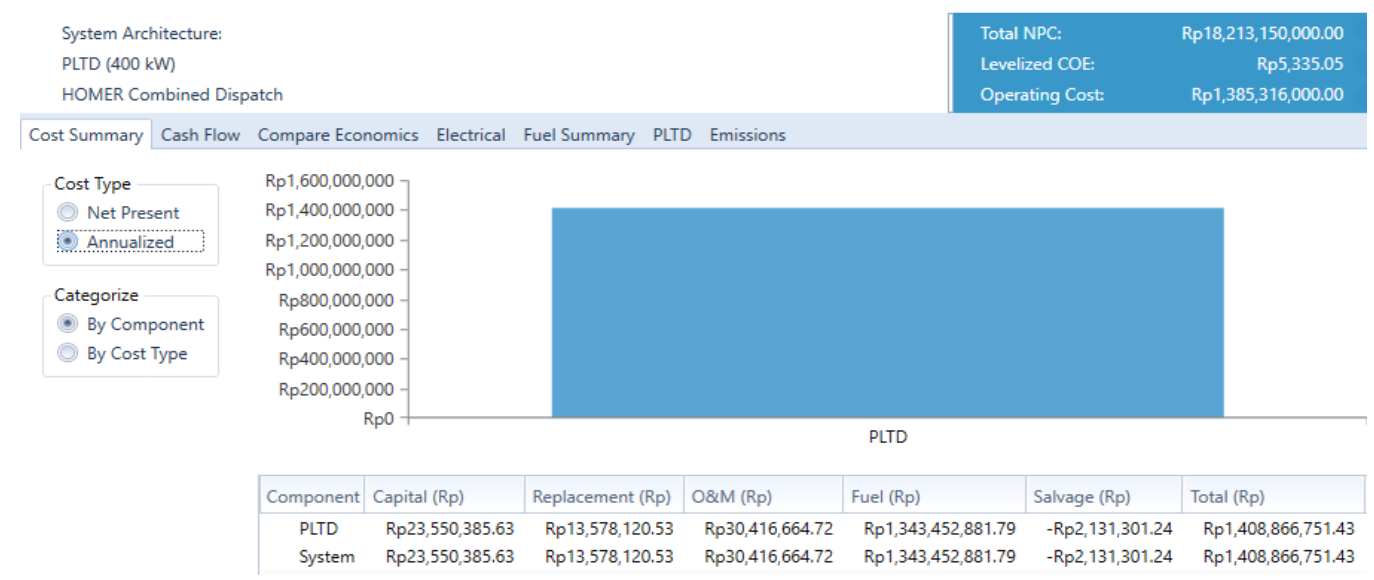

Gambar 11. Annualized Cost PLTD Eksisting Sebelum Dihibrid Dengan PLTS 
Dari Gambar 11 dapat diketahui bahwa biaya tahunan PLTD yang saat ini berada di Pulau Gersik berjumlah Rp. 1.408.866.753,38. Setelah mengetahui biaya tahunan PLTD, maka untuk menentukan LCOE dilakukan perhitungan sebagai berikut:

$\mathrm{LCOE}=(\mathrm{Rp} .1 .408 .866 .751,43) /(264.078 \mathrm{kWh})$

LCOE $=$ Rp. 5.335,05 / kWh

Hasil simulasi yang dilakukan guna mendapatkan LCOE pada sistem pembangkit hibrid dapat dilihat dari Gambar 12.

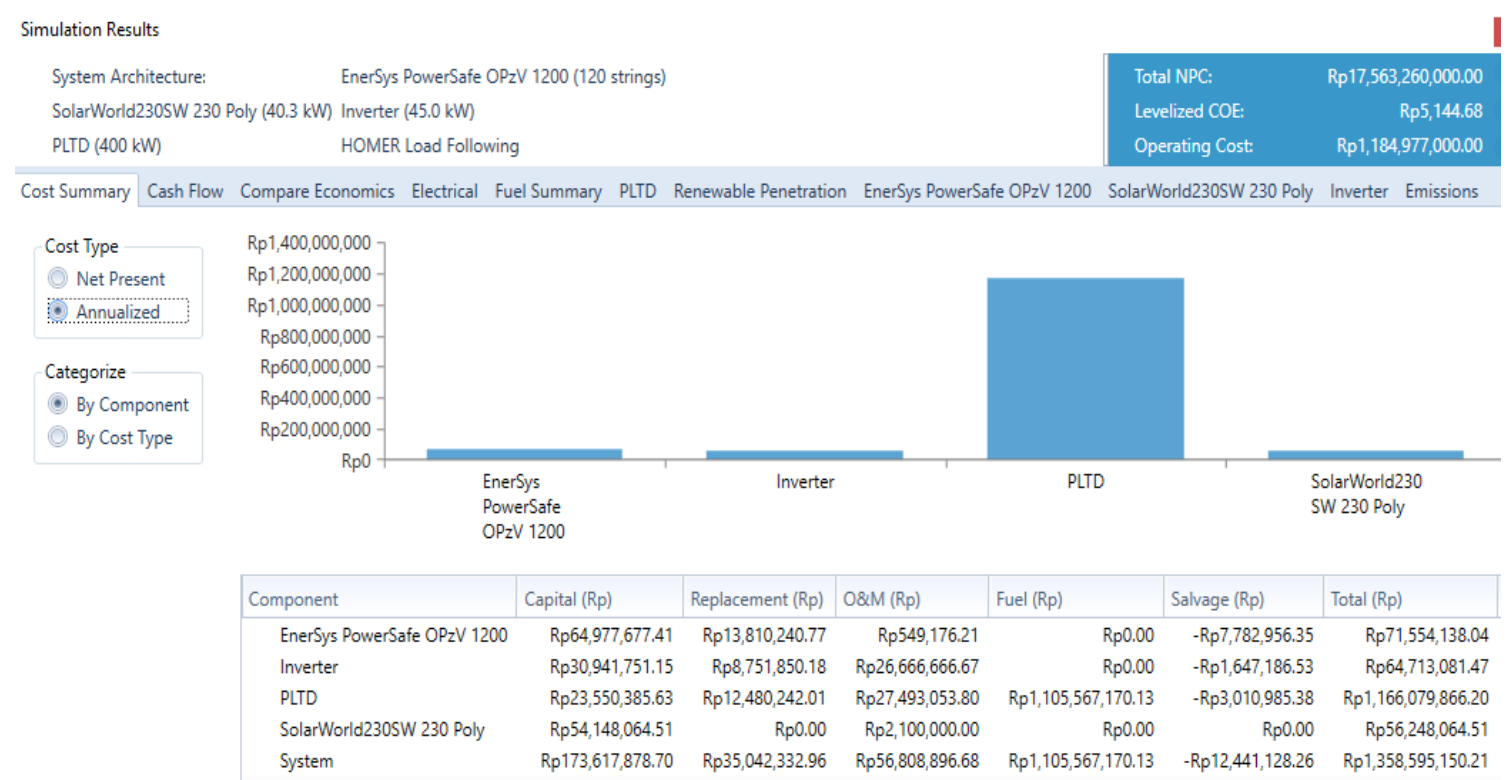

Gambar 12. Annualized Cost PLTD Setelah Dihibrid Dengan PLTS

Dari Gambar 12 dapat diketahui bahwa biaya tahunan sistem pembangkit hibrid yang direncanakan di Pulau Gersik berjumlah Rp. 1.358.595.150,21. Setelah mengetahui biaya tahunan sistem pembangkit hibrid, maka untuk menentukan LCOE dilakukan perhitungan sebagai berikut:

$$
\begin{aligned}
& \text { LCOE }=(\text { Rp. } 1.358 .595 .150,21) /(264.078 \text { kWh }) \\
& \text { LCOE }=\text { Rp. 5.144,68 } / \text { kWh. }
\end{aligned}
$$

Dari perbandingan yang dilakukan maka dapat ditarik kesimpulan bahwasannya LCOE pada sistem pembangkit hibrid yang direncanakan lebih rendah daripada LCOE pada PLTD yang saat ini beroperasi di Pulau Gersik. Oleh karena itu, sistem pembangkit hibrid dapat dikatakan lebih layak untuk digunakan sebagai pembangkit listrik di Pulau Gersik.

\section{KESIMPULAN DAN SARAN}

Simulasi sistem pembangkit hibrid PLTD eksisting dengan PLTS $40 \mathrm{kWp}$ di Pulau Gersik, Belitung telah dilakukan dengan menggunakan perangkat lunak HOMER. Dari hasil simulasi diketahui bahwa sistem pembangkit hibrid layak beroperasi dilihat dari sisi teknis, dengan energi listrik yang dihasilkan adalah $268.101 \mathrm{kWh} / \mathrm{tahun}$. Persentase pembebanan pada sistem hibrid ini adalah $28,9 \%$ dari PLTS dan $71,1 \%$ dari PLTD. 
Dari segi ekonomi, Net Present Cost sistem hibrid yaitu sebesar Rp. 17.184.340.000, lebih rendah daripada NPC PLTD eksisting sebesar Rp. 17.823.080.000. Sedangkan Levelized Cost of Energy sistem hibrid yaitu sebesar Rp. 5.144,68/kWh, juga lebih rendah daripada LCOE PLTD eksisting sebesar Rp. 5.335,05/kWh.

\section{UCAPAN TERIMAKASIH}

Penulis mengucapkan terima kasih kepada Institut Teknologi PLN yang telah memberi dukungan dalam pelaksanaan penelitian melalui Hibah Penelitian Dosen Pemula No. 007/1/B04/PDP/IT-PLN/2021 dan juga ucapan terima kasih kepada PT. PLN (Persero) Unit Induk Wilayah Bangka Belitung.

\section{DAFTAR PUSTAKA}

[1] A. A. Bazmi, G. Zahedi, and H. Hashim, "Progress and challenges in utilization of palm oil biomass as fuel for decentralized electricity generation," Renew. Sustain. Energy Rev., vol. 15, no. 1, pp. 574-583, 2011, doi: 10.1016/j.rser.2010.09.031.

[2] G. A. Marrero and F. J. Ramos-Real, "Electricity generation cost in isolated system: The complementarities of natural gas and renewables in the Canary Islands," Renew. Sustain. Energy Rev., vol. 14, no. 9, pp. 2808-2818, 2010, doi: 10.1016/j.rser.2010.06.007.

[3] G. Alvianingsih, A. Sutra, Y. Arvio, T. R. Sinaga, R. Parman, and I. Garniwa, "The Influence of $\mathrm{NaCl}$ Concentration on Performance of Palm Oil Fuel Heater System," Proceeding - 2020 Int. Conf. Sustain. Energy Eng. Appl. Sustain. Energy Transp. Towar. All-Renewable Futur. ICSEEA 2020, pp. 57-61, 2020, doi: 10.1109/ICSEEA50711.2020.9306182.

[4] G. Alvianingsih et al., "A DESIGN OF PALM OIL FUEL HEATER SYSTEM FOR DIESEL," vol. 19, no. 2, pp. 51-60, 2020.

[5] R. Achmad, "Modul 1 Isu Lingkungan Global," Kim. Lingkung., pp. 1-34, 2004, [Online]. Available: http://repository.ut.ac.id/4658/2/PEKI4312-M1.pdf.

[6] H. D. Ibrahim, N. M. Thaib, and L. M. A. Wahid, "Indonesian Energy Scenario to 2050: Projection of Consumption, Supply Options and Primary Energy Mix Scenarios," A Jt. Symp. Energy links between Russ. East Asia Dev. Strateg. XXI century, p. 2010, [Online]. Available: http://www.sei.irk.ru/symp2010/en/papers.html.

[7] M. U. Khan, M. Hassan, and M. Ali, "Techno-economic Analysis of PV / Wind / Biomass / Biogas Hybrid System for Remote Area Electrification of Southern Punjab ( Multan ), Pakistan using HOMER Pro," 2018 Int. Conf. Power Gener. Syst. Renew. Energy Technol., no. September, pp. 1-6, 2018.

[8] H. Benchraa, A. Redouane, I. El Harraki, and A. El, "Techno-economic feasibility study of a hybrid Biomass / PV / Diesel / Battery system for powering the village of Imlil in High Atlas of Morocco Wood chips."

[9] D. Oleh, "Institut teknologi pln skripsi perancangan plts dalam upaya penghematan bahan bakar pltd di pt. sewatama," 2020.

[10] M. Sukmawidjaja, D. Jurusan, T. Elektro, A. Jurusan, and T. Elektro, "Simulasi Optimasi Sistem Plth Menggunakan Software Homer Untuk," vol. 11, pp. 17-42, 2013.

[11] T. Lambert, P. Gilman, and P. Lilienthal, "Micropower System Modeling with 
Homer," Integr. Altern. Sources Energy, pp. 379-418, 2006, doi: 10.1002/0471755621.ch15.

[12] F. S. Azad, I. Ahmed, S. R. Hossain, and R. Amin Tuhin, "HOMER Optimized Offgrid Hybrid Energy System: A Case Study on Rohingya Relocation Center in Bangladesh," 1st Int. Conf. Adv. Sci. Eng. Robot. Technol. 2019, ICASERT 2019, vol. 2019, no. Icasert, pp. 1-5, 2019, doi: 10.1109/ICASERT.2019.8934534.

[13] A. Iqbal, I. F. Muhammad, M. Faraz, M. S. Tariq, and H. U. Banna, "Economic analysis of a small hybrid power system," 2015 Power Gener. Syst. Renew. Energy Technol. PGSRET 2015, 2015, doi: 10.1109/PGSRET.2015.7312182.

[14] R. Irawati et al., "Hybrid Power Plant Analysis To Fulfill the Electricity Need in Pramuka Island," vol. 11, no. 2, pp. 81-92, 2012.

[15] I. B. Ketut Sugirianta, I. Giriantari, and I. N. Satya Kumara, "Economic Analysis of Solar Electricity Rates using the Life Cycle Cost Method (Analisa Keekonomian Tarif Penjualan Listrik Pembangkit Listrik Tenaga Surya $1 \mathrm{MWp}$ Bangli Dengan Metode Life Cycle Cost)," Maj. IIm. Teknol. Elektro, vol. 15, no. 2, pp. 121-126, 2017. 